\title{
The Civil Rights Litigation Clearinghouse: Origins and Goals
}

\author{
Margo Schlanger ${ }^{1,2}$ \\ 1 Civil Rights Litigation Clearinghouse, US \\ 2 Wade H. and Dores M. McCree Collegiate Professor of Law, University of Michigan, US \\ mschlan@umich.edu
}

The Civil Rights Litigation Clearinghouse (http://clearinghouse.net) solves a significant information deficit related to civil rights litigation by posting information about thousands of ongoing and closed large-scale civil rights cases. Documents are OCR'd and searchable; cases are searchable by metadata tags as well as full-text searching. Each case has a litigation summary by a law student. We live in a civil rights era-a time when people are using the courts, among other strategies, to fight for civil rights. The Clearinghouse posts the records of those fights, the stories of civil rights cases-across topics, across regions, across organizations-and makes them searchable, usable, and available to everybody.

Keywords: archives; civil rights; litigation

I started the Civil Rights Litigation Clearinghouse (http://clearinghouse.net) because when I became a law professor I wanted to focus my research on civil rights injunctive cases: cases in which courts entered and enforced orders that told institutions to change their practices. These included school desegregation cases, prison reform cases, police reform cases, and many other large-scale civil rights matters. Like nearly all cases, most civil rights injunctive cases are not decided by judges. Rather, a negotiated outcome is memorialized in a document, and that document is (as we lawyers say) 'so ordered' by a court. We all live in places affected by such orders: orders changing school policies, transforming housing developments, regulating prisons and jails. They are key features of the American legal landscape. But finding and obtaining the orders and associated documents can be very difficult. You need to start by knowing the case exists, and in what court, and then you need a case name-or, preferably, a docket number. Then you can go to the courthouse (physically or, in more recent years, perhaps virtually) to get the files. Alternatively, you can rely on a good rolodex and call up the lawyers involved in the case and ask them to share information. Either way, only if you start with a good deal of information is there much hope of successfully obtaining further information about these orders-and even then, it is only a hope. This state of affairs is difficult enough if you want to understand one case, or five; it poses extraordinary obstacles to systemic understanding.

My research project was about how prison reform litigation actually functions: not what court opinions say, but how actual implementation works on the ground. (The resulting articles were Schlanger 1999, Schlanger 2003, Schlanger 2006; all are available at margoschlanger.net, under 'publications.') To do that, I needed the pleadings and orders in courthouses and attorneys' files. Because of my own background doing jail and prison litigation, I was able to get permission from the American Civil Liberties Union's on ACLU National Prison Project, the leading national prison litigation organization, to copy and digitize their nonconfidential files. Similarly, I was able to get many early prison and jail civil rights cases' documents from the Department of Justice's Civil Rights Division. I used them myself, and word began to get out that I had the nation's best filing cabinet of jail and prison litigation documents. I began to get emails and phone calls asking for orders and pleadings.

In 2004, I decided to post it all, plus much more. I founded the Civil Rights Litigation Clearinghouse and began to try to build an information infrastructure for civil rights advocates, policymakers, and scholars. It is a labor of love-but not just my labor. Hundreds of students have worked on the project, gathering and 
coding documents, tagging the cases with useful metadata, and writing litigation summaries. Many of our documents were born digital, but many are archival documents, now scanned and digitized. We have been lucky to obtain the papers of a number of retired attorneys, leaders in civil rights litigation who sent along the contents of their basement files. As I write this, we are posting 56,000 documents from over 8000 cases, and we are in process on about 800 more cases. Many are ongoing; for those, we do periodic (though not real-time) updates. For each case, we post, if they are available:

- The complaint: the document that initiates the litigation in trial court,

- Any opinions by trial judges, appellate judges, or the Supreme Court,

- The settlement or other outcome,

- The docket sheet, which functions as an index for the litigation in trial court,

- Other key documents.

For each, a law student has written a summary of the litigation. It is all digitized, OCR'd, tagged, and searchable. Interested in fair lending? Immigration class actions? Cases by the Center for Constitutional Rights or the Bazelon Center or the Asian American Legal Defense and Education Fund? Cases in which your name appears? Check it out.

Civil rights are not merely of historical interest. Right now, we are in a civil rights era-a time when people are fighting for civil rights and often use the courts to amplify their voices and strengthen their bargaining positions. The Clearinghouse posts the records of those fights, the stories of civil rights cases-across topics, across regions, across organizations-and makes them searchable, usable, and available to everybody.

\section{Competing Interests}

The author has no competing interests to declare.

\section{References}

Schlanger, Margo. 1999. "Beyond the Hero Judge: Institutional Reform Litigation as Litigation." Michigan Law Review 97(6): 1994-2036. DOI: https://doi.org/10.2307/1290240

Schlanger, Margo. 2003. "Inmate Litigation." Harvard Law Review 116(6): 1555-1706. DOI: https://doi. org/10.2307/1342709

Schlanger, Margo. 2006. "Civil Rights Injunctions Over Time: A Case Study of Jail and Prison Court Orders." New York University Law Review 81(2): 550-630.

How to cite this article: Schlanger, Margo. 2018. The Civil Rights Litigation Clearinghouse: Origins and Goals. KULA: Knowledge creation, dissemination, and preservation studies 2(1): 16. DOI: https://doi.org/10.5334/kula.40

Submitted: 14 May 2018 Accepted: 11 July 2018 Published: 29 November 2018

Copyright: (c) 2018 The Author(s). This is an open-access article distributed under the terms of the Creative Commons Attribution 4.0 International License (CC-BY 4.0), which permits unrestricted use, distribution, and reproduction in any medium, provided the original author and source are credited. See http://creativecommons.org/ licenses/by/4.0/.

$\mathrm{lu}[\quad K U L A$ : knowledge creation, dissemination, and preservation studies is a peer-reviewed open access journal published by Ubiquity Press 